\title{
EPIDEMIOLOGY OF ANTERIOR CRUCIATE LIGAMENT INJURY IN SOCCER PLAYERS IN THE BRAZILIAN CHAMPIONSHIP
}

\section{EPIDEMIOLOGIA DAS LESÕES DO LIGAMENTO CRUZADO ANTERIOR EM JOGADORES DE FUTEBOL DO CAMPEONATO BRASILEIRO}

\author{
Conrado Tazima Nitta ${ }^{1}$ (i), arthur Rodrigues Baldan ${ }^{1}$ (i), Lucas Plens de Britto Costa ${ }^{1}$ (i), Molses Cohen ${ }^{1}$ (i), \\ Jorge Roberto Pagura ${ }^{1}$ (D), Gustavo Gonçalves ARliani ${ }^{1}$ [D
}

1. Universidade Federal de São Paulo, Department of Orthopedics and Traumatology, Sports Traumatology Center, São Paulo, SP, Brazil.

\section{ABSTRACT}

Objective: To evaluate and collect epidemiological data on injuries of the anterior cruciate ligament of the knee in professional soccer players of the Brazilian Championship. Methods: Transversal study, with information extracted from the online data platform www.transfermrkt.com.br (Transfermarkt GmbH \& Co. KG), with 5 seasons (2015 - 2019) of the Brazilian championship series A and $B$ being analyzed and revised by 3 researchers. Results: 52 injuries of the anterior cruciate ligament were detected, with a mean age of 26,3 years, time off due to injury of $244.5 \pm 31.6$ days, regardless of the division. Forwarders and defenders had the highest incidences of injury without statistically significant difference, but they had greater chances than goalkeepers, left/right backs and midfielders. Conclusion: The incidence of injury to the anterior cruciate ligament of the knee in professional football players in the first and second divisions of the Brazilian soccer championship between 2015 and 2019 is 0.414 per 1,000 hours of play, a value similar to described in the literature. The incidence of the injury varies according to the player's field position, being the forwarders and defenders the most injured players. Level of Evidence II, Retrospective study.

Keywords: Soccer. Athletes. Anterior Cruciate Ligament. Epidemiology.

\section{RESUMO}

Objetivo: Avaliar dados epidemiológicos das lesões do ligamento cruzado anterior do joelho em jogadores profissionais de futebol do Campeonato Brasileiro. Métodos: Estudo transversal, com informações extraídas da plataforma de dados on-line www.transfermrkt. com.br (Transfermarkt GmbH \& Co. KG), sendo analisadas 5 temporadas (2015 - 2019) do campeonato brasileiro séries A e B por 3 pesquisadores. Resultados: Detectamos 52 lesões do ligamento cruzado anterior, com idade média de 26,3 anos, tempo de afastamento devido a lesão de 244,5 +- 31,6 dias, independentemente da série. Atacantes e zagueiros apresentaram maiores incidências de lesão sem diferença estatisticamente significante entre eles, porém apresentaram maiores chances que goleiros, laterais e meio campistas. Conclusão: A incidência da lesão do ligamento cruzado anterior do joelho em atletas de futebol do campeonato brasileiro série $A$ e $B$ entre 2015-2019 é de 0,414 por 1.000 horas de jogo, semelhante ao descrito em literatura. A incidência da lesão depende da posição tática do jogador, com atacantes e zagueiros sofrendo mais lesões em relação as outras posições. Nível de Evidência II, Estudo retrospectivo.

Descritores: Futebol. Atletas. Ligamento Cruzado Anterior. Epidemiologia.

Citation: Niita CT, Baldan AR, Costa LPB, Cohen M, Pagura JR, Arliani GG. Epidemiology of anterior cruciate ligament injury in soccer players in the Brazilian championship. Acta Ortop Bras. [online]. 2021;29(1):45-8. Available from URL: http://www.scielo.br/aob.

\section{INTRODUCTION}

Created in England in 1863, soccer is the most popular sport in the world. In Brazil, that is not different. With 662 professional teams, Brazilian soccer is responsible for producing great players on an international level.
The Brazilian Football Confederation (CBF) estimates that only in the first six months of 2019 there was movement of 213 million euros in sales of athletes abroad. ${ }^{1}$

In this scenario, it is not difficult to understand that the entire absence of a professional player, even for only a few days, results in high

All authors declare no potential conflict of interest related to this article.

The study was conducted at Universidade Federal de São Paulo, Department of Orthopedics and Traumatology, Sports Traumatology Center. Correspondence: Conrado Tazima Nitta. Rua Estado de Israel, 636, Vila Clementino, São Paulo, SP, Brazil, 04022-001. conradonitta@gmail.com 
costs for a team. The costs increase in cases of injuries that cause long time off, as in the case of the anterior cruciate ligament injury, in which player's time off can vary between nine and 12 months. ${ }^{2-4}$ Since soccer is a sport that requires abrupt changes of direction at high speeds, sudden decelerations and high contact, it predisposes the athlete's knee to high axial loads combined with pivot movements, ${ }^{5-7}$ representing high risk for anterior cruciate ligament injury. ${ }^{8-11}$ And, in addition to the prolonged time away from the sport after three years of injury, only $65 \%$ of players return to their pre-injury level. ${ }^{12}$ Therefore, preventive programs for the anterior cruciate ligament injury in professional soccer are necessary. Thus, studies on this subject are essential to understand the frequency and severity of these injuries within an actual population of professional soccer players. ${ }^{12-17}$ In this context, study aims at evaluating epidemiological data on anterior cruciate ligament injuries of the knee among players participating in the major soccer league in Brazil, the Brazilian National Soccer Championship.

\section{MATERIALS AND METHODS}

This transversal descriptive study was approved by the Research Ethics Committee of the Universidade Federal de São Paulo in the opinion number $1,660,701$.

The information in this study was extracted from the public access online data platform www.transfermrkt.com.br (Transfermarkt $\mathrm{GmbH} \& \mathrm{Co} . \mathrm{KG}$ ), in which professional information, market value, statistical and injury data of soccer players from the main soccer club leagues in the world can be found. The published data are periodically reviewed and updated, with validity and accuracy of the injuries recorded in the Transfermarkt online database. ${ }^{18}$

The online data platform was accessed and five seasons (2015 2019) of the Brazilian Soccer Championship first and second divisions were analyzed and reviewed by three researchers.

In each season of the Brazilian Championship, both in first and second divisions, 20 teams with varied squads participate, playing with each other twice, counted 38 rounds, totaling 380 matches and 12,540 hours played per season.

For the investigation of previous cruciate ligament injuries in soccer players in the Brazilian championship, the players enrolled in the Brazilian championships first and second divisions between 2015 and 2019 were surveyed for the existence of this injury in the period studied. All players that had the anterior cruciate ligament injury identified were analyzed for age at the time of the injury, tactical position in the team, season at the time of the injury (cold or hot warm) and time off due to injury.

The incidence of the anterior cruciate ligament injury was defined as the new cases divided by the total of players in a given time. The incidence of injury for 1,000 played hours was also analyzed according to Fifa's incidence formula.

$$
\text { Incidence }=\frac{\text { number of injuries }}{\text { played hours }} \times 1000
$$

SPSS V20, Minitab 16, and Excel Office 2010 software were used. For quantitative variables, descriptive analysis was performed. The comparison of continuous variables was analyzed by the $t$-student test. To characterize the distribution and relative frequency of qualitative variables, we used the Two Proportions Equal Test, analysis of statistical confidence intervals defined as 95\% and P-value defined as less than or equal to 0.05 .

\section{RESULTS}

We identified 52 previous cruciate ligament injuries on first and second division soccer players in the Brazilian championship between the seasons 2015 and 2019, a total of 8,121 players and 125,400 played hours. The overall incidence found was $0.0064 \%$, with an average of 10.4 injuries per season added to the $A$ and $B$ series. There were 0.26 team injuries per season, corresponding to approximately 1 injury per team every 4 seasons.

The incidence of injury per 1,000 hours played in first and second divisions was 0.414 . Performing the stratification of the incidences between first and second division, we observed a 0.574 incidence in the first division, against 0.255 in the second throughout the studied period (95\%Cl, p-value 0.005, OR 2.13), showing 2.13 times more chances players get injured in first division than in the second (Table 1).

Figure 1 shows the proportion of injuries in the first and second divisions.

\begin{tabular}{|c|c|c|c|c|c|}
\hline & Injuries & Hours & Incidence & $p$-value & Odds Ratio \\
\hline General & 52 & 125,400 & 0.414 & & \\
\hline First Division & 36 & 62,700 & 0.574 & \multirow{2}{*}{0.005} & \multirow{2}{*}{$\begin{array}{c}2.13 \\
\text { (1.18 to } 3.85)\end{array}$} \\
\hline \multirow[t]{3}{*}{ Second Division } & 16 & 62,700 & 0.255 & & \\
\hline & 32 & 84,018 & 0.380 & \multirow{2}{*}{0.401} & \multirow{2}{*}{$\begin{array}{c}1.60 \\
(0.92 \text { to } 2.80)\end{array}$} \\
\hline & 20 & 41,382 & 0.483 & & \\
\hline Forward & 25 & 125,400 & 0.199 & Ref. & $\begin{array}{c}8.36 \\
\text { (2.52 to 27.69) } \\
\end{array}$ \\
\hline Goalkeeper & 3 & 125,400 & 0.0239 & $<0.001$ & Ref. \\
\hline Left/right Back & 3 & 125,400 & 0.0239 & $<0.001$ & Ref. \\
\hline Midfielder & 4 & 125,400 & 0.0318 & $<0.001$ & $\begin{array}{c}1.33 \\
(0.30 \text { to } 5.96)\end{array}$ \\
\hline Central defender & 17 & 125,400 & 0.135 & 0.216 & $\begin{array}{c}5.68 \\
(1.66 \text { to } 19.38)\end{array}$ \\
\hline
\end{tabular}

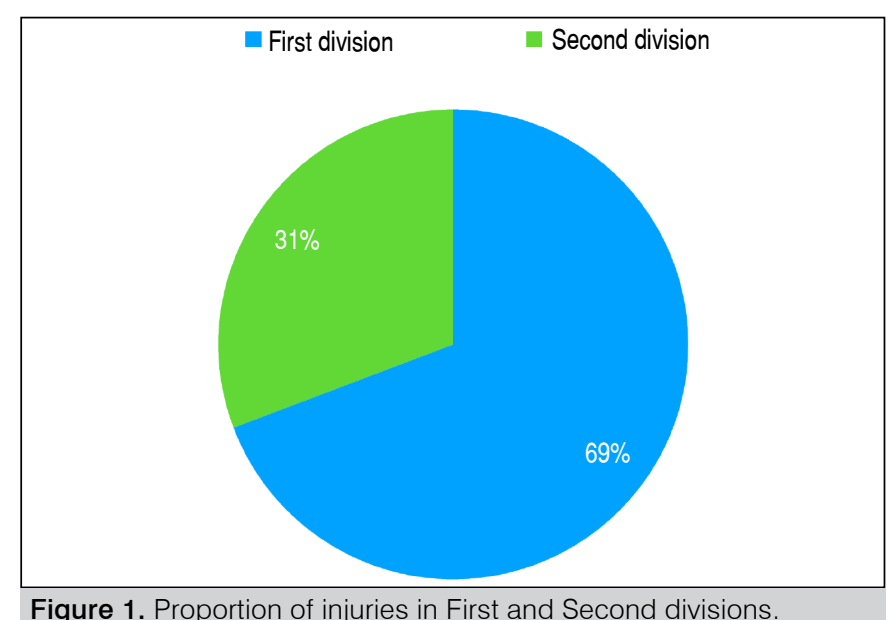

Figure 1. Proportion of injuries in First and Second divisions.

Regarding the time when the injury occurred - warm (spring and summer) and cold seasons (fall and winter) - a higher incidence was observed during the warm seasons, 0.483 against 0.380 during the cold seasons. However, this difference is not statistically significant, considering the confidence interval of $0.92-2.8$. Since the Brazilian championship starts in April and ends in December, the number of hours played in each season is different, having 84,018 hours being played in the coldest seasons of the year, whereas 41,382 hours were played during the warmest seasons (Table 1). Figure 2 illustrates the distribution of injuries that occurred throughout the Brazilian championship calendar. 


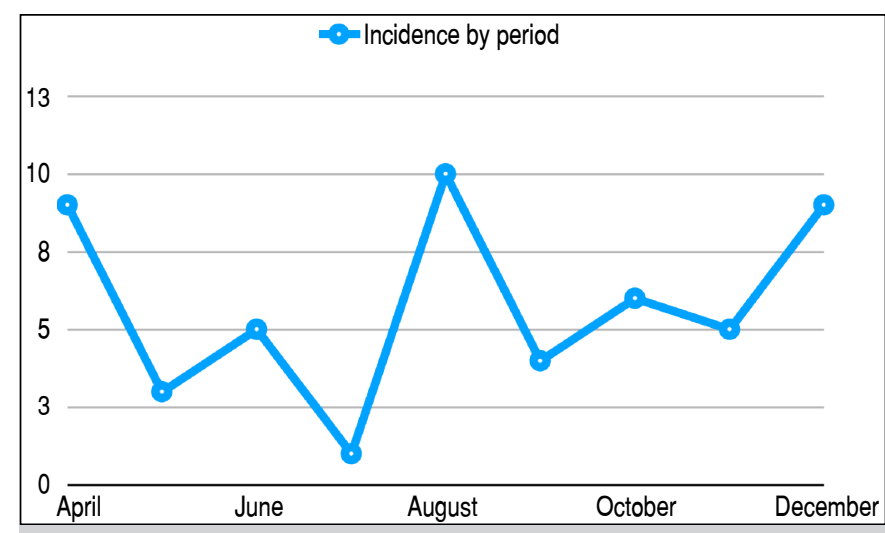

Figure 2. Distribution of injuries throughout the Brazilian Championship.

Analyzing the incidences segmented according to the players' tactical position, we found a higher incidence of the studied injury in forwarders, 25 injuries in total, representing a 0.199 incidence per 1,000 hours played. Thus, for statistical significance ( $p$-value), we chose to use the incidence of injury in forwarders as a reference (0.199 injuries every 1,000 hours played). The difference between the incidence of injury between forwarders and defenders showed no statistical significance ( $p$-value $=0.216$ ), but between goalkeepers, laterals and midfielders a statistically significant difference was observed ( $p$-value $<0.001$ ). To determine the odds ratio (Odds Ratio) between the incidences of injuries in the different tactical positions, we chose to adopt the reference value (0.0239 injuries every 1,000 hours played) of the position with the lowest incidence, goalkeepers and backs, with three injuries each, representing 0.0239 injuries per 1,000 played hours. Thus, forwarders had 8.36 times more chances of injury compared to goalkeepers and defenders, and defenders, 5.68 times more chances than goalkeepers. Midfielders, in turn, had 1.33 times more chance to present injuries when compared with goalkeepers and defenders, but this value does not present statistical significance, considering the 95\% confidence interval (0.30 to 5.96 ) in this comparison (Table 1 ). Figure 3 shows the incidences of injuries according to the players' tactical position.

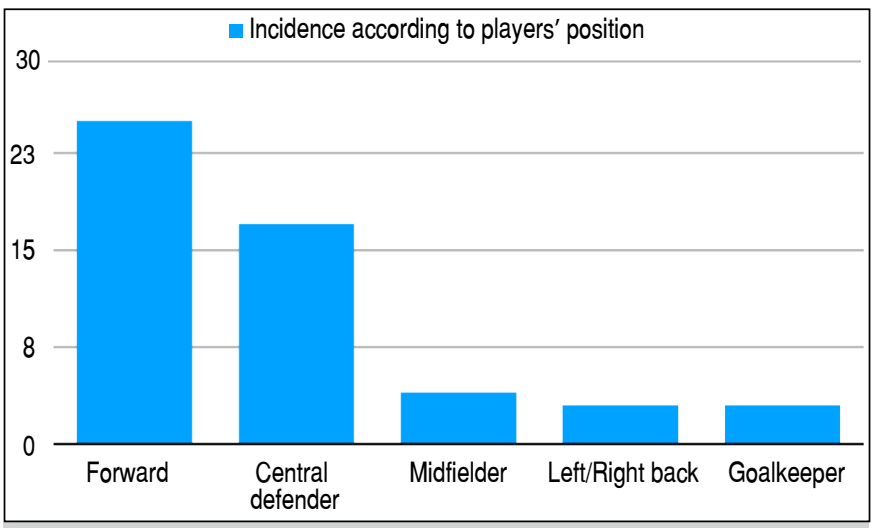

Figure 3. Incidence of injuries according to the players' position.

The average age of the players that suffered the injuries was 26.3 years, with no difference with statistical significance between players in the first and second divisions ( $p$-value $=0.749$ ).

The mean number of days off due to the anterior cruciate ligament injury between the players of first and second divisions ( $p$-value $=0.492)$ was similar, observing that the mean time off in both divisions was $244.5 \pm 31.6$ days. It can also be affirmed that the variation regarding the time of withdrawal in first division low (Coefficient of Variation $<50 \%$ ), reflecting a greater homogeneity of data. On the other hand, the same cannot be said for the time off in second division, which presents Coefficient of Variation $>50 \%$ (Table 2).

Table 2. Age distribution of injuries and time off.

\begin{tabular}{|c|c|c|c|c|c|c|c|c|c|c|}
\hline \multicolumn{2}{|c|}{ Division } & \multirow{2}{*}{\begin{tabular}{|c|} 
Mean \\
26.3 \\
\end{tabular}} & \multirow{2}{*}{\begin{tabular}{|c|} 
Median \\
26 \\
\end{tabular}} & \multirow{2}{*}{\begin{tabular}{|c|}
$\begin{array}{c}\text { Standard } \\
\text { Deviation }\end{array}$ \\
4.8 \\
\end{tabular}} & \multirow{2}{*}{$\begin{array}{l}\text { VC } \\
18 \%\end{array}$} & \multirow{2}{*}{\begin{tabular}{r|} 
Min \\
19
\end{tabular}} & \multirow{2}{*}{\begin{tabular}{|l|} 
Max \\
36 \\
\end{tabular}} & \multirow{2}{*}{\begin{tabular}{|l|}
$N$ \\
52 \\
\end{tabular}} & \multirow{2}{*}{\begin{tabular}{c|}
$\mathrm{Cl}$ \\
1.3 \\
\end{tabular}} & \multirow[t]{2}{*}{ P-value } \\
\hline \multirow{3}{*}{$\begin{array}{l}\text { Age at } \\
\text { the injury }\end{array}$} & Both & & & & & & & & & \\
\hline & $\begin{array}{c}\text { First } \\
\text { Division }\end{array}$ & 26.5 & 26 & 4.9 & $19 \%$ & 19 & 36 & 36 & 1.6 & \multirow{2}{*}{0.749} \\
\hline & $\begin{array}{l}\text { Second } \\
\text { Division }\end{array}$ & 26.0 & 26 & 4.8 & $19 \%$ & 19 & 33 & 16 & 2.4 & \\
\hline \multirow{3}{*}{ Time off } & Both & 244.5 & 214 & 116.4 & $48 \%$ & 97 & 800 & 52 & 31.6 & \\
\hline & $\begin{array}{c}\text { First } \\
\text { Division }\end{array}$ & 252.0 & 219 & 112.6 & $45 \%$ & 150 & 800 & 36 & 36.8 & \multirow{2}{*}{0,492} \\
\hline & $\begin{array}{l}\text { Second } \\
\text { Division }\end{array}$ & 227.6 & 188 & 126.7 & $56 \%$ & 97 & 651 & 16 & 62.1 & \\
\hline
\end{tabular}

\section{DISCUSSION}

The age profile of players with anterior cruciate ligament injuries found in our study is similar to the profile of players found in the literature. The average age of 26.3 years found is similar to the 25.2 years reported in a European cohort study with the main European leagues ${ }^{19}$ and to the 25.0 years found in professional players of Quatar. ${ }^{16}$

Likewise, the $244.5 \pm 31.6$ days off is similar to the period observed in previous studies. ${ }^{2-4}$ this similarity also occurred between the first and second divisions. There may be many explanations for such a difference, from biological factors inherent to graft healing and integration and to standardization of rehabilitation protocols. Previous studies claim that the highest incidence of anterior cruciate ligament injury in soccer occurs in defenders. ${ }^{20-23}$ Contrary to the literature, we observed a higher incidence of injuries among forwarders, but with no statistically significant difference compared to defenders ( $p$-value $=0.216$ ). This result can be explained, since the aforementioned studies consider both right/ left backs and central defenders as defenders. In our study, these two tactical positions were stratified. We can consider that forwarders and defenders presented the highest incidence of injury (0.199 and 0.135 , respectively), since these are tactical positions that, not coincidentally, require abrupt changes of direction at high speeds, sudden decelerations and high contact, predisposing the knee to high axial loads combined with pivot movements, a common trauma mechanism of the injury studied. ${ }^{5-7}$ Goalkeepers, in turn, can be considered more "jumpers", left/right backs, more "runners" midfielders tend to orbit the midfield at lower speeds.

Finally, the 52 injuries found in our study over five seasons, in a universe of 8,121 players and 125,400 played hours, showed an incidence of 0.414 injuries per 1,000 played hours, with an average of 10.4 injuries per season in first and second divisions combined, 0.26 injuries per team per season, corresponding to approximately one injury per team every four seasons. Such results are consistent with those observed in the literature. A study by Alberto Grassi, published in Sport Health in 2019. ${ }^{24}$ showed 0.421 injuries per 1,000 hours played in the first division of the Italian championship, and Waldén et al. ${ }^{12}$ obtained slightly lower results than those found in our study (0.309 injuries), in the main European leagues, which can still be considered close.

We notice a big difference when analyzing the incidences of injury in the first and second divisions of the Brazilian 
championship separately. In the first division, the incidence found is 0.574 , whereas in the second, 0.255 . The low incidence of injuries in the second division ends up reducing the general average of injuries in Brazilian players, making the final product of the incidences of both series of the Brazilian championship equivalent to that found in the literature. However, this discrepancy masks an increased incidence of injuries in the first division of the Brazilian championship compared to the literature, to the detriment of a lower incidence in the second division. This increased incidence of injuries in the first division is a phenomenon that can be explained by the intense schedule of matches in the major teams in the country, since these players tend to play in matches of different competitions at the same period, especially when representing their national teams. This is not an exclusive routine of the main Brazilian teams, also happening in Europe; however, the Brazilian teams may not be equally prepared for this intensity of matches, both from the point of view of the extension of the squad, and the technical and physical preparation due. This is a hypothesis that could explain the discrepancy of this data with international literature. However, the low incidence of injury in the second division has yet to be clarified. One hypothesis is the underreporting of injuries and the loss of follow-up of players that present these injuries in this soccer segment. The second division Brazilian soccer presents less investment, and, consequently, health care. In this context, we assume that a player suffering a previous cruciate ligament injury may not have the injurydiagnosed or reported.

\section{CONCLUSION}

In short, we can conclude that the incidence of anterior cruciate ligament injury of the knee in professional soccer players of the Brazilian championship first and second divisions between 2015 and 2019 is 0.414 for every 1,000 hours of play, a figure similar to that described in literature. The average age at the time of injury and 23.6 years and time off due to injury is $244.5 \pm 31.6$ days, regardless of the division. Forwarders and defenders presented the highest incidence of injury, without statistically significant difference; however, they presented higher chances than goalkeepers, left/right backs and midfielders. All the epidemiological data cited in our study can be used by teams and professionals related to soccer to implement measures that can contribute to the prevention and faster recovery of injuries in professional athletes.

AUTHORS' CONTRIBUTIONS: Each author contributed individually and significantly to the development of this article. CTN: writing of the article, review, survey of epidemiological data in the platform used, statistical analysis; ARB: writing of the article, review, survey of epidemiological data in the platform used; LPBC: review, survey of epidemiological data in the platform used; MC: review of the article, intellectual concept of the article; JRP: writing and review of the article and also the entire intellectual concept of the article; GGA: writing of the article, statistical analysis and intellectual concept of the article and preparation of the entire research project.

\section{REFERENCES}

1. International Federation of Association Football. FIFA.com [Internet]. Zurich: [2020]. [accessed on 2020 Nov 26]. Available from: http://pt.fifa.com

2. Lai CCH, Ardern CL, Feller JA, Webster KE. Eighty-three per cent of elite athletes return to preinjury sport after anterior cruciate ligament reconstruction: a systematic review with meta-analysis of return to sport rates, graft rupture rates and performance outcomes. Br J Sports Med. 2018;52(2):128-38.

3. Zaffagnini S, Grassi A, Marcheggiani Muccioli GM, Trapralis K, Ricci M, Bragonzoni L, et al. Return to sport after anterior cruciate ligament reconstruction in professional soccer player. Knee. 2014;21(3):731-5.

4. Zaffagnini S, Grassi A, Serra M, Marcacci M. Return to sport after ACL reconstruction: how, when and why? A narrative review of current evidence. Joints. 2015;3(1):25-30.

5. Agel J, Rockwood T, Klossner D. Collegiate ACL injury rates across 15 sports: National Collegiate Athletic Association Injury Surveillance System Data Update (2004-2005 through 2012-1013). Clin J Sport Med. 2016;26(6):518-23.

6. Gornitzky AL, Latt A, Yellin JL, Fabricant PD, Lawrence JT, Ganley TJ. Sport-specific yearly risk and incidence of anterior cruciate ligament tears in high school athletes: a systematic review and meta-analysis. Am J Sport Med. 2016;44(10):2716-23.

7. Takahashi S, Okuwaki T. Epidemiological survey of anterior cruciate ligament injury in Japanese junior high school and high school athletes: cross-section study. Res Sport Med. 2017;25(3):266-76.

8. Grassi A, Carulli C, Innocenti M, Mosca M, Zaffagnini S, Bait C, et al. New trends in anterior cruciate ligament reconstruction: a systematic review of national surveys of the last 5 years. Joints. 2018;6(3):177-87.

9. Kaeding CC, Léger-St-Jean B, Magnussen RA. Epidemiology and diagnosis of anterior cruciate ligament injuries. Clin Sports Med. 2017;36:1-8.

10. Montalvo AM, Schneider DK, Yut L, Webster KE, Beynnon B, Kocher MS, et al. "What's my risk of sustaining an ACL injury while playing sports?" A systematic review with meta-analysis. Br J Sports Med. 2019;53(16):1003-12.

11. Moraes ER, Arliani GG, Lara PHS, Silva EHR, Pagura JR, Cohen M. Orthopedic injuries in men's professional soccer in Brazil: prospective comparison of two consecutive seasons 2017/2016. Acta Ortop Bras, 2018;26(5):338-41.

12. Waldén $M$, Hägglund $M$, Magnusson $H$, Ekstrand J. ACL injuries in men's professional football: a 15 -year prospective study on time trends and return-to play rates reveals only $65 \%$ of players still play at the top level 3 years after ACL rupture. Br J Sports Med. 2016;50(12):744-50.
13. Junge A, Dvořák, J. Football injuries during the 2014 FIFA World Cup. Br J Sports Med. 2015;49(9):599-602.

14. Dvorak J, Junge A, Derman W, Schwellnus M. Injuries and illness of football players during the 2010 FIFA World Cup. Br J Sports Med. 2011;45(8):626-30

15. Niederer D, Engeroff T, Wilke J, Vogt L, Banzer W. Return to play, performance and career duration after anterior cruciate ligament rupture: a case-control study in the five biggest football nations in Europe. Scand J Med Sci Sports. 2018;28(10):2226-33.

16. Rekik RN, Tabben M, Eirale C, Landreau P, Bouras R, Wilson MG, et al. $A C L$ injuryy incidence, severity and patterns in professional male soccer players in Middle-Eastern League. BMJ Open Sport Exerc Med. 2018;23(4):e000461.

17. Schiffner E, Latz D, Grassman JP, Schek A, Thelen S, Windolf J, et al. Anterior cruciate ligament ruptures in German elite soccer players: epidemiology, mechanism, and return to play. Knee. 2018;25(2):219-25.

18. Leventer L, Eek F, Hofstetter S, Lames M. Injury patterns among elite football players: a media-based analysis over 6 seasons with emphasis on plying position. Int J Sports Med. 2016;37(11):898-908.

19. Waldén M, Hagglund M, Magnusson H, Ekstrand J. Anterior cruciate ligament injury in elite football: a prospective three-cohort study. Knee Sports Traumato Arthrosc. 2011;19(1):11-9.

20. Brophy RH, Stepan JG, Silvers HJ, Mandelbaum BR. Defending puts the anterior cruciate ligament at risk during soccer: a gender-based analysis. Sport Health. 2015;7(3):244-9

21. Della Villa F, Maldelbaum BR, Lemak LJ. The effect os playing position on injury risk in male soccer players: systematic review of the literature and risk considerations for each playing position. Am J Orthop (Belle Maed NJ). 2018;47(10).

22. Grassi A, Smiley SP, Robert di Sarsina T, Singorelli C, Muccioli GMM, Bondi $A$, et al. Mechanisms and situations of the anterior cruciate ligament injuries in professional male soccer players: a YouTube-based video analysis. Eur J Orthop Sure Traumatol. 2017;27(7):967-81.

23. Waldén M, Krosshaug T, Bjorneboe J, Andersen TE, Faul O, Hägglund M. Three distinct mechanisms predominate in non-contact anterior cruciate ligament injuries in male professional football players: a systematic video analysis of 39 cases. Br J Sports Med. 2015;49(22):1452-60.

24. Grassi A, Macchiarola L, Filippini M, Lucidi GA, Della Villa F, Zaffagnini S. Epidemiology of anterior cruciate ligament in Italian First Division soccer players. Sports Health. 2020;12(3):279-88. 